\title{
TPR (TOTAL PHYSICAL RESPONSE) METHOD ON TEACHING ENGLISH TO EARLY CHILDHOOD
}

\author{
Ruli Hafidah, Nurul Kusuma Dewi \\ Pendidikan Guru Pendidikan Anak Usia Dini, Universitas Sebelas Maret \\ rulihafidah@staff.uns.ac.id
}

\begin{abstract}
This training is carried out to provide knowledge and skills to PAUD teachers in implementing English language learning for early childhood. The subjects of the training were 30 Kindergarten (Kindergarten) and PAUD teachers of Bendosari kindergarten. The training is carried out in 3 stages, namely: (1) strengthening of materials related to the TPR (Total Physical Response) method in early childhood learning; (2) implementation of the TPR (Total Physical Response) method in learning aged children; and (3) evaluation of the material for the TPR (Total Physical Response) method in learning children. Training on the application of the TPR (Total Physical Response) method in learning English for early childhood can improve the understanding, abilities and skills of Kindergarten and PAUD teachers in the District, Sukoharjo Regency in compiling, developing, and implementing English learning using the TPR (Total Physical Response) method. Where the deepening of the material for each training stage reaches $90 \%$. This is evidenced by the results of practice and the implications of each material. Kindergarten and PAUD teachers in Bendosari Subdistrict, Sukoharjo Regency can develop themes and materials, create and use media, choose English vocabulary according to themes and materials, and apply English learning using the TPR (Total Physical Response) method.
\end{abstract}

Keywords: TPR, English learning, teaching early childhood

\section{METODE TPR (TOTAL PHYSICAL RESPONSE) DALAM PEMBELAJARAN BAHASA INGGRIS UNTUK GURU-GURU PAUD}

\begin{abstract}
Abstrak: Pelatihan ini dilaksanakan untuk memberikan pengetahuan dan keterampilan kepada guru-guru PAUD dalam melaksanakan pembelajaran bahasa inggris anak usia dini. Subjek pelatihan adalah guru-guru PAUD keacamatan Bendosari sebanyak 30 guru TK (Taman Kanak-Kanak) dan PAUD. Pelatihan dilaksanakan dalam 3 tahap, yaitu: (1) penguatan materi terkait metode TPR (Total Physical Respon) dalam pembelajaran anak usia dini; (2) implementasi metode TPR (Total Physical Respon) dalam pembelajaran anak usia; dan (3) evaluasi materi metode TPR (Total Physical Respon) dalam pembelajaran anak usia. Pelatihan penerapan metode TPR (Total Physical Respon) pada pembelajaran bahasa inggris anak usia dini dapat meningkatkan pemahaman, kemampuan dan keterampilan guru TK dan PAUD Kecamatan, Kabupaten Sukoharjo dalam menyusun, mengembangkan, dan menerapkan pembelajaran bahasa inggris dengan metode TPR (Total Physical Respon). Dimana pendalaman materi setiap tahap pelatihan mencapai $90 \%$. Hal ini dibuktikan dengan hasil praktek dan impilkasi setiap materi. Guru-guru TK dan PAUD kecamatan Bendosari, Kabupaten Sukoharjo dapat mengembangkan tema dan materi, membuat dan menggunakan media, memilih kosa kata bahasa inggris sesuai tema dan materi, serta menerapkan pembelajaran bahasa inggris dengan metode TPR (Total Physical Respon).
\end{abstract}

Kata kunci: metode TPR, Pembelajaran Bahasa Inggris, Guru PAUD 


\section{PENDAHULUAN}

Seiring dengan perkembangan ipteks dalam dunia pendidikan dan semakin besarnya kebutuhan untuk komunikasi di kancah global serta adanya tuntutan masyarakat khususnya orang tua terhadap lembaga pendidikan, banyak lembagalembaga pendidikan anak usia dini (PAUD) baik formal maupun nonformal yang meliputi TK dan playgroup terutama di kota-kota besar seperti kota Surakarta kini mulai mengenalkan bahasa Inggris kepada peserta didik melalui pembelajaran harian atau program ekstrakurikuler. Pembelajaran bahasa Inggris ini diberikan pada aktivitas mengawali pembelajaran, di tengah pembelajaran, dan pada saat menjelang pulang, baik dengan secara langsung mengenalkan kosakata tematik dengan tema-tema yang yang disesuaikan dengan tema pembelajaran di kurikulum, misalnya: alpbabet, number, animals, fruit, colours, family members, dan sebagainya, baik dengan menggunakan media flashcard, atau benda asli dan tiruannya, maupun lewat lagu berbahasa Inggris.

Dasar pengenalan bahasa Inggris kepada anak usia dini (AUD) ini dimulai dengan pemberian kosakata sederhana tersebut dengan lebih ditekankan pada pengucapan kata-kata bahasa Inggris secara benar dan tulisannya. Pembelajaran bahasa Inggris di PAUD tentu saja dikemas dengan menggunakan metode pembelajaran yang menarik dan menyenangkan seperti melalui permainan, yang tentu saja disesuaikan dengan tingkat perkembangan dan prinsip pembelajaran anak usia dini, yaitu belajar melalui bermain. Pemberian pembelajaran bahasa (bahasa Inggris) di PAUD berdasarkan Permendikbud no 137 tahun 2014 tentang standar nasional PAUD pasal 10 yang menyebutkan tentang pengembangan bidang bahasa terdiri atas: 1). memahami bahasa reseptif, mencakup kemampuan memahami cerita, perintah, aturan, menyenangi dan menghargai bacaan; 2). mengekspresikan bahasa, mencakup kemampuan bertanya, menjawab pertanyaan, berkomunikasi secara lisan, menceritakan kembali yang diketahui, belajar bahasa pragmatik, mengekspresikan perasaan, ide, dan keinginan dalam bentuk coretan; dan 3). keaksaraan, mencakup pemahaman terhadap hubungan bentuk dan bunyi huruf, meniru bentuk huruf, serta memahami kata dalam cerita. Dalam permendikbud tersebut secara global hanya menyebutkan pengembangan bahasa sehingga dapat dimaknai bahwa diperbolehkan memberikan bahasa Inggris (bahasa asing) pada AUD sepanjang tetap menggunakan pembelajaran yang mengikuti prinsip pembelajaran untuk AUD dan sesuai dengan tingkat perkembangan AUD.

Pemberian atau pengenalan bahasa Inggris untuk AUD pada dasarnya memiliki banyak manfaat yaitu anak mampu menguasai bahasa asing sehingga memiliki kelebihan dalam hal intelektual yang fleksibel, keterampilan akademik, berbahasa dan social, sehingga anak akan mempunyai kemampuan yang lebih baik untuk hidup ditengah masyarakat yang memiliki keberagaman social serta budaya. Beberapa penelitian tentang fungsi otak (brain research) juga menyatakan bahwa sejak usia dini anak sudah bisa belajar dua bahasa (bilingual) sekaligus baik bahasa ibu (first language) dan juga bahasa kedua (second language) akan tetapi harus konsisten dalam penerapannya dan berlangsung terus menerus. Dan para ahli AUD juga mengatakan sangat baik bagi seorang anak untuk belajar bahasa kedua atau bahasa ketiganya sebelum dia berusia 10 tahun, artinya kemampuan belajar bahasa kedua/ketiga anak akan lebih baik jika dia belajar sebelum usia 10 tahun. Selain itu anak usia TK dan PAUD (4-6 thn) berada pada masa emas (golden age) yang memerlukan banyak kegiatan untuk menstimulus semua aspek perkembangan. Dengan demikian 
semakin banyak stimulus yang diberikan semakin baik untuk perkembangan anak. Dengan dasar uraian di atas maka TK-TK mulai mengenalkan bahasa Inggris kepada anak didiknya. Permasalahannya adalah bagaimana mengajarkan bahasa Inggris tersebut kepada AUD? Tentunya dengan menggunakan metode pembelajaran yang tetap berpijak pada prinsip belajar AUD yakni belajar melalui bermain dengan mengacu pada DAP (Developmentally Appropriate Practice) yakni pembelajaran harus disesuaikan dengan tingkat perkembangan anak secara terus menerus melalui pembelajaran yang bermakna, menarik dan menyenangkan.

Kenyataannya dilapangan membuktikan bahwa guru TK dan PAUD di Kec Bendosari Kab. Sukoharjo, hanya beberapa TK yang telah berani memberikan pembelajaran bahasa Inggris dan guru yang mengajarkan bahasa Inggris kepada anakanak tersebut adalah guru kelas mereka sendiri yang tidak memiliki background pendidikan bahasa Inggris maupun background PAUD (yang di dalamnya juga sudah diberikan tentang pembelajaran bahasa Inggris untuk AUD). Hal ini berakibat pembelajaran bahasa Inggris di TK-TK di Kab. Sukoharjo belum maksimal. Hal ini dikarenakan guru hanya menggunakan LKA (Lembar Kerja Anak) atau dengan flashcards sederhana dan benda-benda tiruannya dengan metode konvensional/ceramah atau seadanya untuk mengenalkan kosakata bahasa Inggris. Metode pembelajaran bahasa inggris pada anak usia dini dengan menggunakan metode ceramah atau konvensional. Anak hanya ditunjukkan flashcards atau benda tiruannya, kemudian guru memberikan kosakata bahasa Inggrisnya atau guru meminta anak untuk mengerjakan LKA. Dengan mengerjakan LKA, anak hanya duduk dalam waktu tertentu. Hal ini berarti anak tidak diajak untuk melakukan kegiatan yang disesuaikan dengan masa tumbuh kembang anak yang dikaitkan dengan fisik motorik anak. Dengan kata lain, anak tidak diberikan pengalaman bervariasi dalam pembelajaran bahasa Inggris dengan kegiatan, media/alat peraga edukatif atau benda riil yang ada disekitar anak sehingga anak merasa bosan dengan metode pembelajaran dan media yang monoton tersebut. Sehingga dapat dikatakan tidak ada variasi metode atau teknik pembelajaran yang membuat anak semangat, termotivasi dan tertarik untuk belajar bahasa Inggris. Selain itu dengan metode yang digunakan guru, kosakata bahasa Inggris susah dipahamiatau dihapal anak karena lepas dari konteks situasi dan kurang bermakna bagi anak. Dengan kata lain anak hanya disuruh menghapal kosakata bahasa Inggris dan anak jarang diajak menggunakan kosakata tersebut dalam bentuk kalimat sederhana percakapan sehingga anak akan cepat lupa dengan kosakata tersebut jika tidak direview. Atau guru jarang menggunakan kosakatakosakata bahasa Inggris yang sudah diberikan dan dihapal anak dalam bentuk kalimat sederhana dalam situasi pembelajaran. Sehingga hasil pembelajaran bahasa Inggris belum bisa maksimal. Untuk pelafalan kosakata bahasa Inggris yg diucapkan gurunya pun juga masih kurang tepat/ banyak salah. Kesalahan pelafalan dari guru tersebut tentu akan ditiru oleh anak dan dibawa sampai di level pendidikan berikutnya jika tidak ada pihak yang berupaya untuk membenarkannya dan anak menyadari kesalahan pelafalan tersebut.

Berdasarkan uraian di atas dapat dirumuskan permasalahan guru-guru PAUD khususnya di kecamatan Bendosari, antara lain: (1) pengetahuan guru-guru PAUD di kecamatan Bendosari Kabupaten Sukoharjo tentang metode pembelajaran bahasa Inggris yang menarik, menyenangkan, efektif, bermakna, dan sesuai dengan karakteristik perkembangan untuk anak usia dini masih 
kurang, (2) kemampuan guru yang mengajarkan bahasa Inggris ke AUD tersebut terutama tentang pelafalan kosakata tematik bahasa Inggris masih sangat kurang karena guru tersebut tidak memiliki background pendidikan bahasa Inggris dan masih sedikit yang memiliki background PAUD (yang di dalamnya juga sudah diberikan tentang pembelajaran bahasa Inggris untuk AUD),

\section{TPR (Total Physical Respon)}

Suhendan (2013) [1] menjelaskan bahwa metode TPR cocok diterapkan dalam pembelajaran bahasa bagi anak usia dini yaitu: Pertama. TPR berkaitan dengan gaya/tipe belajar anak. Pada dasarnya anakanak perlu untuk bergerak karena mereka memiliki energy yang sangat besar dan memiliki jangkauan perhatian yang pendek/singkat. Anak sering berinteraksi dengan lingkungannya dan tertarik dengan hal-hal yang bersifat fisik dan nyata. Menurut Scott dan Ytreberg dalam Suhendan (2013) bahwa hal yang dominan dalam pemahaman anak berasal dari hal-hal yang berkaitan dengan tangan, mata, telinga, dan dunia fisik anak lainnya. Jika kegiatan dalam TPR adalah permainan, hal ini cocok untuk anak-anak yang memiliki tipe belajar kinestetik. Mereka akan belajar yang terbaik ketika melakukan sesuatu secara fisik atau menghubungkan dengan memorinya melalui gerakan. Selain tipe pembelajar kinestetik, metode TPR juga berhubungan dengan anak yang memiliki tipe belajar visual yang mengambil visual/gambar dengan melihat gerakan yang dihubungkan dengan kalimat-kalimat perintah yang diberikan. Ketika metode TPR diikuti dengan lagu atau nyanyian, anak-anak yang memiliki tipe belajar auditory akan mendapatkan manfaat dari kata-kata dan ritme lagu yang dikaitkan dengan gerakan yang akan dikenang anak (Reilly dan Ward dalam Suhendan, 2013).
Kedua. Teks independen/bebas. Pada dasarnya tidak ada teks dasar pada pembelajaran TPR. Pada tahap awal pembelajaran menggunakan TPR boleh tidak menggunakan materi karena suara, gerakan, dan gesture guru sudah cukup digunakan untuk kegiatan-kegiatan di dalam kelas. Guru dapat menggunakan benda-benda yang umumnya ada di dalam kelas seperti buku, mainan, boneka, furniture, dan sebagainya (Richards dan Rodgers dalam Suhendan, 2013). Menurut Pinter (Suhendan, 2013) bagi anak-anak yang berusia di bawah tujuh tahun yang belum mampu menulis dan membaca, guru perlu untuk menyiapkan kegiatan-kegiatan yang tidak berkaitan dengan kertas dan pensil. Kegiatan-kegiatan kebanyakan diterapkan pada hal-hal yang diucapkan atau gambar juga dapat digunakan. Anak dapat menunjuk benda ketika suatu kata diucapkan guru. Dan ketika suatu cerita dibacakan guru, anak dapat menirukan gerakannya. Ketiga. Menyenangkan dan menarik. TPR tidak menyebabkan anak berada di bawah tekanan atau menyebabkan anak stress. Melalui kegiatan-kegiatan kebahasaan di dalam kelas yang penuh dengan lagu-lagu, gerak dan lagu, serta cerita dan gerakan, anak-anak akan merasa senang dan terus diupayakan agar anak menikmati setiap proses dalam melakukan kegiatan tersebut (Mirici dalam Suhendan, 2013). Dengan menggunakan metode TPR selain dapat menghilangkan stress anak juga dapat menciptakan suasana hati yang positif dari anak didik sehingga dapat memfasilitasi pembelajaran. Dan pada akhirnya dapat meningkatkan motivasi dan prestasi anak dalam pembelajaran bahasa asing (bahasa Inggris). Keempat. Bilateral. Menurut Richards dan Rodgers (Suhendan, 2013) Metode TPR memiliki dua fitur. Pertama, seperti diketahui bahwa kegiatan kebahasaan dikoordinasikan oleh otak kiri sedangkan kegiatan fisik dikoordinasikan oleh otak kanan. Dengan menggunakan TPR dalam 
pembelajaran bahasa akan membantu anak untuk menggunakan dua bagian otak tersebut (Asher dalam Suhendan, 2013). Kedua, ketika mempelajari satu bahasa dan anak fokus pada gerakan-gerakannya, sehingga anak akan memperoleh bahasa tersebut tanpa disadarinya. Hal ini tentu akan mengurangi stress pada anak ketika mereka mempelajari bahasa tersebut.

\section{Prinsip Pembelajaran Anak Usia Dini}

Proses pembelajaran pada Anak Usia Dini tidak lepas dari kurikulum sebagai acuan pembelajaran, tapi kurikulum tersebut bersifat fleksibel dalam mengembangkan dan melaksanakanannya pada anak usia dini. Kurikulum yang digunakan dapat dikembangkan sesuai dengan prinsip pembelajaran anak usia dini. Prinsip pembelajaran anak usia dini meliputi beberapa hal, sebagai berikut "berorientasi pada kebutuhan anak, bermain sambil belajar, kreatif dan inofatif, mengembangkan keterampilan hidup, berorientasi pada perkembangan anak" (Partini, 2011) [2]. Sedangkan pada (Depdiknas, 2002: 5) [3] menjabarkan pendekatan dalam pembelajaran anak usia dini, yaitu: (1) berorientasi pada kebutuhan anak, (2) belajar melalui bermain, (3) kreatif dan inovatif, (4) lingkungan yang kondusif, (5) menggunakan pembelajaran terpadu, (6) mengembangkan keterampilan hidup, (7) Menggunakan berbagai media dan sumber belajar, (8) berorientasi pada prinsip-prinsip perkembangan anak, (9) stimulasi terpadu, saat anak melakukan suatu kegiatan aspek-aspek perkembangan anak dapat distimulasi secara bersamaan"

Guru harus memberikan stimulasi pada anak untuk mengembangkan aspek kemampuan anak. Kegiatan pembelajaran pada anak harus berorientasi pada kebutuhan anak, karena anak usia dini adalah anak yang sedang membutuhkan upaya-upaya pendidikan untuk mencapai optimalisasi semua aspek perkembangan, baik perkembangan fisik maupun spikis. Selain itu, pembelajaran harus dilaksanakan dengan bermain yang menyenangkan. Melalui kegiatan bermain anak diajak untuk berekplorasi, menemukan, dan memanfaatkan benda-benda di sekitar. Isi kurikulum yang digunakan hendaknya fleksibel. Dalam pembalajaran anak usia dini guru harus mampu menciptakan proses belajar mengajar yang mengasyikkan, rileks dan menyenangkan untuk anak. Guru tidak hanya terpaku untuk menerapkan metodemetode pembelajaran yang sudah ada, tetapi harus selalu kreatif dan inovatif menemukan metode-metode pembelajaran yang baru dan modern serta harus sesuai dengan tema sebagai materi pembelajaran untuk anak usia dini.

Guru harus menciptakan lingkungan yang kondusif, menarik, menyenangkan, nyaman, dan sebagai sumber belajar anak dalam proses pembelajaran. Pembelajaran pada anak usia dini harus dapat menstimulasi semua aspek perkembangan sehingga pembelajaran harus dibuat terpadu atau terintegrasi yang dikembangkan dari satu yang dekat dengan anak dan dipilih dari kejadian keseharian anak. Guru harus memberikan keterampilan hidup pada anak dalam pembelajaran dengan cara pembiasaan mandiri agar anak mampu menolong dirinya sendiri, disiplin, bersosialisasi agar anak dapat hidup dan tinggal di masyarakat, empati, dan tanggung jawab. Proses pembelajaran anak usia dini tidak terlepas dari media dan sumber belajar, karena pada usia ini anak masih belajar secara konkrit tentang apa yang anak lihat, dengar, dan lakukan. Penjabaran diatas sesuai dengan pendapat Suyanto (2005) [4] menyatakan bahwa pembelajaran TK bersifat terpadu dan terintegrasi.

Katz (Masitoh, dkk. 2005: 14) [5] mengemukakan "bahwa dalam merencanakan kurikulum harus didasarkan 
pada pemahaman perkembangan berikutnya". Siklus belajar anak berulang dari membangun kesadaran, memulai eksplorasi, dan memperoleh penemuan. Anak belajar dari interaksi sosial dengan orang dewasa dan teman sebaya. Motivasi belajar anak berasal dari minat dan keingintahuan anak terhadap sesuatu yang menarik. Perkembangan dan belajar anak harus memperhatikan perbedaan individual. Anak belajar dari cara sederhana ke rumit, dari konkrit ke abstrak, dari gerakan keverbal, dan dari egois ke rasa sosial.

Penerapan metode TPR (Total Physical Response) pada pembalajaran anak usia dini harus dilaksanakn dengan menggunakan prinsip-prinsip pembelajaran anak usia dini. TPR (Total Physical Response) diterapkan dalam pembelajaran bahasa Inggris anak usia dini dengan media konkret, miniatur, gambar, alam, dsb. Penerapan metode TPR (Total Physical Response) dilakukan dengan kegiatan bermain yang menyenangkan terutama permainan motorik sehingga anak dapat aktif bergerak. Kosa kata bahasa inggris yang akan dikenalkan pada anak usia dini disesuai dengan tema dan kegiatan seharihari anak. Kosa kata bahasa inggris yang bisa dianjarkan dalam pembelajaran anak usia dini melalui metode TPR (Total Physical Respons) antara lain: kata benda, kata kerja, kata ganti, sehingga kosa katakosa kata bahasa inggris yang dikenalkan dapat dikenalkan dengan media dan gerak sesuai instruksi guru.

\section{METODE PENELITIAN}

Kegiatan pengabdian dilakukan di Kecamatan Bendosari, Kabupaten Sukoharjo. Tujuan kegiatan pengabdian bertujuan untuk meningkatkan kemampuan dan keterampilan guru-guru PAUD Kecamatan Bendosari, Kabupaten Sukoharjo dalam melaksanakan pembelajaran bahasa Inggris anak usia dinidengan menggunakan metode TPR (Total Physical Respon). Subjek adalah 30 guru TK dan PAUD Kecamatan Bendosari, Kabupaten Sukoharjo. Kegiatan pengabdian dilakukan dengan beberapa tahapan, yaitu:

1. Penguatan Materi

Pelaksanaan pelatihan metode TRP (Total Physical Respon) dalam pembelajaran anak usia dini untuk guru-guru PAUD. Materi yang diberikan antara lain: konsep TPR (Total Physical Respon), pengembangan perangkat pembelajaran, media pembelajaran untuk menerapkan TPR (Total Physical Respon), dan kosa kata bahasa inggris untuk anak usia dini. Pada tahap penguatan materi dilaksanakan sebanyak 2 kali, pada hari pertama materi yang diberikan adalah konsep TPR (Total Physical Respon) dan kosa kata bahasa inggris untuk anak usia dini. Sedangkan pada hari kedua materi yang diberikan adalah mengembangkan perangkat pembalajaran pada pembelajaran bahasa inggris anak usia dini dan media pembelajaran untuk pembelajaran bahasa inggris anak usia dini.

2. Penugasan dan Praktek

Pada tahap kedua pelatihan dilakukan dengan memberikan penugasan dan praktek. Pada tahap penugasan dan praktek dilaksanakan dalam 2 kali pertemuan, yaitu: hari pertama kegiatan pelatihan adalah penugasan dan hari kedua adalah praktek dikelas. Pada kegiatan hari pertama peserta diberikan pendampingan untuk menyusun perangkat pembelajaran bahasa inggris dengan metode TPR (Total Physical Respon) dan membuat media sesuai dengan tema/sub.tema pembelajaran. Perangkat dan media disusun untuk diimplementasikan pada pembelajaran dikelas. Pada hari kedua peserta menerapkan perangkat pembelajaran dan media yang sudah disusun pada hari sebelumnya pada pembelajaran dikelas. Guru melaksanakan pembelajaran bahasa inggris dengan metode TPR (Total Physical Respon) pada anak-anak dikelas. 
3. Evaluasi dan Tindak Lanjut

Tahap evaluasi dan tindak lanjut dilakukan pada akhir pertemuan. Evaluasi bertujuan untuk mengetahui kesesuaian tahap perencaan dan pelaksanaan, mengukur tingkat keberhasilan dari pelatihan, serta mengetahui pemahaman guru dalam mengimplikasikan pembelajaran bahasa inggris dengan metode TPR (Total Physical Respon) untuk anak usia dini. Tahap evaluasi dilakuakn dengan metode wawanca dan laporan akhir melalui praktek langsung. Hasil evaluasi dapat digunakan untuk bahan pertimbangan kerjasama, studi awal penelitian, dan pengembangan program.

\section{HASIL DAN PEMBAHASAN}

Hasil pelatihan pembelajaran bahasa inggris dengan metode TPR (Total Physical Respon) pada anak usia dini dampak positif dan mengalami peningkatan. Hal ini dibuktikan dengan hasil observasi dan wawancara guru-guru dapat mendalami meteri, dapat membuat perencanaan, media dan melaksanakan pembelajaran bahasa inggris untuk anak usia dini. Guru-guru yang pada awalnya tidak penah melakukan pembelajaran bahasa inggris untuk anak usia dini menjadi semangat melakukan pembeljaaran bahasa inggris pada setiap kegiatan pembelajaran dikelas, peserta sudah dapat mengembangkan perangkat pembelajaran bahasa inggris, peserta juga dapat menggunakan media dan metode TPR (Total Physical Respon). peserta dapat melakukan pembelajaran bahasa inggris anak usia dini dengan keratif, inovatif dan menyenangkan sehingga guru dan anak dapat belajar bahasa inggris dengan menyenangkan, Pembelajaran dalam TPR disusun berdasarkan tata bahasa/grammar bahasa Inggris dan penggunaan kalimat perintah/command. Guru akan memberikan berbagai bentuk kalimat perintah menggunakan kata kerja yang dapat dilakukan dengan fisik motorik anak dan kosakata dalam pembelajaran yang diberikan. Sehingga fokus utama dalam TPR adalah pemahaman arti/meaning melalui kalimat perintah dengan berbagai kosakata yang diberikan. Anak mendengarkan dengan penuh perhatian dan merespon secara fisik atas perintah yang diberikan guru, baik secara individu maupun kelompok.

Metode TPR dapat dengan mudah digunakan dalam kegiatan rutin harian di dalam kelas. Guru mendorong anak-anak untuk mengenali dan merespon instruksi sederhana yang diberikan guru, seperti: sit down, stand up, shake hand, open, close, dan sebagainya. Guru dapat membuat visual yang dihubungkan dengan kosakata agar dapat dipelajari dan ditiru oleh anak, khususnya untuk kata-kata deskriptif atau kata sifat, misalnya big, small, happy, sad, angry, dan sebagainya. Hal ini tentu akan tersimpan dalam ingatan anak dan hasilnya mereka akan menyukai untuk menirukan tentang profesi, binatang, tanaman, kondisi/cuaca dan sebagainya. Hal ini sesuai dengan yang dikemukakan oleh Pinter dalam Suhendan (2013) bahwa dengan metode TPR ini, anak pertama akan mendengarkan kosakata yang diucapkan guru, kemudian memahami pesan/makna kosakata tersebut, selanjutnya memutuskan mereka salah atau benar, dan terakhir mereka melakukan gerakannya. Reilly dan Ward (Suhendan, 2013) menyatakan bahwa permainan merupakan komponen penting dalam pembelajaran anak usia dini. Anak-anak menyukai untuk melakukan permainan. Dan permainan yang terkenal salah satunya adalah permainan Simon says yang dapat dihubungkan dengan kosakata bagian-bagian anggota badan, kata kerja dan objek yang dapat disentuh/dipegang oleh anak. Permainan ini merupakan permainan tebak kata yang isinya menirukan dan menebak menggunakan gambar atau kartu kata. Permainan ini sangat mudah dilakukan di dalam kelas. 
Selain permainan terdapat lagu atau nyanyian yang juga sangat penting dalam pembelajaran anak usia dini. Ketika lagu atau nyanyian yang dilakukan berbarengan dengan gerakan dalam pembelajara bahasa asing/Inggris, hal ini pada dasarnya membangun elemen-elemen dari metode TPR dan sekaligus membuat anak memahami makna lagu tersebut lebih baik. Sehingga diperlukan lagu-lagu yang berisi kata-kata/lirik yang diulang-ulang yang mudah dipahami dan diingat anak. Dalam penelitian ini peneliti juga menggunakan gerak dan lagu. Sebagai contoh ketika guru akan mengenalkan kosakata bagian dari wajah. Guru mengajarkan gerakangerakannya terlebih dulu yaitu dengan mengenalkan bagian-bagian wajah dengan cara diucapkan dan didemonstrasikan, misalnya: point to your nose, show me your ears, touch your eyes, dan sebagainya. Setelah anak memahami bagian-bagian wajah tersebut, selanjutnya guru menyanyikan sendiri atau memutar lagu dari kaset atau video yang liriknya berisi tentang bagian-bagian wajah tersebut dan mendorong anak untuk bergerak sesuai dengan maknanya. Pengulangan dari lagu dan gerakannya sangat penting bagi anak, karena kebiasaan ini akan menimbulkan rasa percaya diri anak dan membantu anak memahami hal-hal yang dipelajarinya.

Selain permainan dan lagu, storytelling juga merupakan kegiatan yang sangat autentik dan terkenal bagi semua anak. Tidak ada anak yang tidak menyukai cerita. Melalui kegiatan bercerita, anak akan memperoleh bahasa baru dengan mudah karena suatu cerita berisi pengulangan yang membuat input kebahasaan lebih jelas (Pinter dalam Suhendan, 2013). Makanya dalam penelitian ini peneliti juga menggunakan storytelling. Dalam kegiatan bercerita yang dikaitkan dengan TPR, anak menirukan cerita yang disampaikan guru, melakukan gerakan yang tidak diarahkan ketika mereka mendengar kata-kata kunci dibaca guru, mendengarkan dan berdiri ketika karakter ceritanya berbicara dan berakting, melihat dan menunjuk ilustrasi kunci dari cerita tersebut. Gerakan-gerakan tersebut membuat cerita lebih hidup dan membantu anak tanpa sadar menginternalisasikan bahasanya. Cerita yang terdapat gerakan-gerakan di dalamnya akan membantu anak merasakan bahwa mereka memahami bahasa dari proses awalnya, yaitu: mendengarkan, melihat, dan menirukan. Secara bertahap anak akan memahami bahasa secara holistik.

Penerapan metode TPR (Total Physical Respon) dalam pembelajaran bahasa Inggris untuk anak usia dini dapat dilaksanakan dengan kata-kata kunci dikenalkan kepada anak melalui gambar atau flashcard. Kemudian kata-kata tersebut diulang oleh guru secara perlahan-lahan beberapa kali dalam suatu urutan (plane, doll...). Anak selanjutnya memahami katakata tersebut. Dalam melakukan hal ini, hal yang terpenting adalah menyesuaikan kecepatan guru mengajar dan kecepatan anak dalam belajar. Selanjutnya kalimat-kalimat yang berupa command /kalimat perintah dikenalkan kepada anak secara bertahap satu demi satu secara berurutan, seperti fly plane, hug doll...). Guru mengulangi beberapa kali satu kalimat perintah sebelum diberikan kalimat perintah berikutnya. Guru harus membuat urutan yang tetap ketika menyampaikan kalimat-kalimat perintah tersebut. Selanjutnya guru dapat membuat urutan secara acak dari kalimat-kalimat perintah tersebut dan diharapkan anak dapat menirukan gerakan dari kalimat perintah yang sudah diacak urutannya tersebut. Terakhir, gambar-gambar dari kata-kata dan kalimat-kalimat perintah diberikan kepada anak-anak. Anak-anak kemudian diminta untuk menuliskan huruf berdasarkan urutan gerakan yang diberikan. 


\section{SIMPULAN}

Pelatihan penerapan metode TPR (Total Physical Respon) pada pembelajaran bahasa inggris anak usia dini dapat meningkatkan pemahaman, kemampuan dan keterampilan guru TK dan PAUD Kecamatan, Kabupaten Sukoharjo dalam menyusun, mengembangkan, dan menerapkan pembelajaran bahasa inggris dengan metode TPR (Total Physical Respon). Dimana pendalaman materi setiap tahap pelatihan mencapai $90 \%$. Hal ini dibuktikan dengan hasil praktek dan impilkasi setiap materi. Guru-guru TK dan PAUD kecamatan Bendosari, Kabupaten Sukoharjo dapat mengembangkan tema dan materi, membuat dan menggunakan media, memilih kosa kata bahasa inggris sesuai tema dan materi, serta menerapkan pembelajaran bahasa inggris dengan metode TPR (Total Physical Respon).

Penerapan metode TPR (Total Physical Respon) pada pembelajran bahasa inggris ini mempunyai potensi yang sangat besar dalam mengaktifkan anak dalam memahami bahasa asing atau bahasa Inggris yang dipelajari anak. Penggunaan metode TPR dalam pembelajaran bahasa Inggris sebagai bahasa asing pada pembelajaran anak usia dini juga memberikan manfaat untuk anak, yaitu: metode ini dapat untuk membangun kosakata anak, membantu anak untuk segera memahami bahasa target atau bahasa Inggris, memfasilitsi anak untuk belajar dengan makna dalam konteks nyata, pembelajaran lebih menyenangkan bagi anak, anak terlibat secara langsung dalam pembelajaran, merangsang anak untuk belajar, kinestetik anak juga berkembang

\section{DAFTAR PUSTAKA}

[1] Suhenda. "Using Total Physical Response Method in Early Childhood Foreign Language Teaching
Environment". Social and Behavioral Sciences, 93 (2013) 1766 - 1768.

[2] Partini. Pengantar Pendidikan Anak Usia Dini. Yogyakarta: Grafindo Litera Media. 2010.

[3] Depdiknas. (2002). Acuan Menu Pembelajaran pada Pendidikan Anak Dini Usia (Menu Pembelajaran Generik). Jakarta: Direktorat PAUD. 2002.

[4] Suyanto, S. (2005). Pembelajaran untuk Anak TK. Jakarta: Depdiknas.

[5] Masitoh, dkk. Pendekatan Belajar Aktif di Taman Kanak-Kanak. Jakarta: Depdiknas. 2005. 